DOI: https://doi.org/10.32836/2521-666X/2020-69-14

УДК 331.451

\author{
Рубцова О.C. \\ кандидат економічних наук, доцент, \\ Київський національний університет будівництва і архітектури \\ ORCID: https://orcid.org/0000-0002-9078-0105
}

\title{
Rubtsova Oksana
}

Kyiv National University of Construction and Architecture

\section{БУДІВНИЦТВО ЯК ЗАСІБ РЯТУВАННЯ ЕКОНОМІКИ В УМОВАХ ФОРС-МАЖОРНИХ ОБСТАВИН (SARS-COV-2)}

\section{CONSTRUCTION AS A MEANS OF SAVING THE ECONOMY IN CASE OF FORCE MAJEURE (SARS-COV-2)}

\begin{abstract}
У статті проведено аналіз впливу форс-мажорних обставин на економіку розвинутих країн, в яких із поширенням вірусу SARS-CoV-2 відбулося зниження ВВП. Підприємства багатьох галузей економіки відчули вплив карантинних заходів на свою роботу. Будівництво у зв'язку з особливостями ведення виробничого процесу може стати однією з галузей, які дають змогу мінімізувати вплив коронавірусної кризи й утримати економіку від надшвидких темпів рецесії. Запропоновано низку дій щодо залучення персоналу будівельних підприємств до робочого процесу в негативних умовах впливу пандемії. Зважаючи на високий рівень впливу обмежувальних заходів, введених Кабінетом міністрів України, на роботу суб'єктів господарювання, до будівельного прочесу пропонується залучення виробничого персоналу в умовах мінімального ризику зараження для зниження розповсюдження інфекиії серед населення країни, оскільки державі необхідно мінімізувати ризики на ринку праці.
\end{abstract}

Ключові слова: форс-мажор, карантинні заходи, аналіз, соиіальне дистаниіювання, аутсорсинг, аутстафінг.

В статье проведен анализ влияния форс-мажорных обстоятельств на экономику развитых стран, в которых с распространением вируса SARS-CoV-2 произошло снижение ВВП. Предприятия многих отраслей экономики почувствовали влияние карантинных мероприятий на свою работу. Строительство в связи с особенностяли ведения производственного процесса может стать отраслью, которая позволит минимизировать влияние коронавирусного кризиса и удержать экономику от сверхбыстрых темпов рецессии. Предложен ряд действий по привлечению персонала строительных предприятий к рабочему процессу в негативных условиях влияния пандемии. Несмотря на высокий уровень влияния ограничительных мер, введенных Кабинетом министров Украинь, на работу субъектов хозяйствования, к строительному проиессу предлагается привлечение производственного персонала в условиях минимального риска заражения для снижения распространения инфекции среди населения страны, поскольку государству необходимо минимизировать риски на рынке труда.

Ключевые слова: форс-мажор, карантинные мероприятия, анализ, сочиальное дистанцирование, аутсорсинг, аутстаффинг.

The article analyzes the impact of force majeure on the economies of developed countries, where the spread of the SARS-CoV-2 virus has led to a decline in GDP. Enterprises in many sectors of the economy have felt the impact of quarantine measures on their work in the form of reduced production, and even the cessation of activities. which led to a decrease in key financial indicators. Construction, due to the peculiarities of the production process, can be one of the industries that will minimize the impact of the coronavirus crisis and keep the economy from a very fast recession. A number of actions have been proposed to involve construction personnel in the work process, which will allow construction companies to operate in the negative conditions of the pandemic. Given the high level of impact of restrictive measures imposed by the Cabinet of Ministers of Ukraine on the work of economic entities, the construction process is proposed to involve production staff with minimal risk of contamination, which, accordingly, will include construction companies in the list of organizations that may not apply. prohibition of current activities, because to reduce the spread of infection among the population, the state needs to minimize risks in the labor market. In the context of the global crisis caused by the spread of coronavirus attack and the resulting negative economic and social transformations, there is a need to assess the impact of force majeure on the economic condition of the world's leading economies at the macro- and microlevels. The research is burdened by the lack of statistical observations, due to the short period of time from the date of entry into force of quarantine measures in the world and the lack of possibility to calculate the continuation of restrictive factors. The model of involvement of the personnel in production process for the purpose of performance of conditions of social distancing at workplaces of the enterprises of the building industry is offered. The primary task facing the company is to minimize the impact of force majeure on the activities of the organization, which will lead to the stabilization of the country's economy

Key words: force majeure, quarantine measures, analysis, social distancing, outsourcing, outstaffing.

Постановка проблеми. В умовах глобальної кризи, спричиненої розповсюдженням світом коронавірусної атаки та викликаних нею негативних економічних та соціальних трансформацій, виникає необхідність оцінити вплив форс-мажорних обставин на економічний стан провідних економік світу на макро- та мікрорівнях. До- слідження обтяжується недостатньою кількістю статистичних спостережень у зв'язку з невеликим проміжком часу з дати початку дії карантинних заходів в країнах світу і відсутністю можливості розрахунку продовження дії обмежувальних факторів. Запропоновано модель залучення персоналу у виробничий процес із метою вико- 
нання умов соціального дистанціювання на робочих місцях підприємств будіндустрії. Нині перед усіма галузями економіки стоїть головне завдання мінімізації впливу форс-мажорів на поточну діяльність та пошуку ефективних заходів щодо ефективної роботи підприємств, пристосування суб'єктів господарювання до нових реалій існування. Актуальність цього дослідження полягає у пошуку шляхів стабілізації роботи підприємств будівельної галузі та адаптації до нових умов праці в умовах пандемії.

Аналіз останніх досліджень та публікацій. Питання функціонування будівельних підприємств у сучасних умовах досліджувалися цілою низкою вітчизняних учених, таких як В.I. Торкатюк, А.Ф. Гойко, С.А. Ушацький, Є.В. Бондаренко та інші. Концепцією розвитку суб'єктів господарювання будівельної галузі під впливом кризових явищ займалися: А.М. Асаул, І.В. Борщук та інші. Але ж подібні кризові явища (пандемії) вже багато років не спостерігалися, тому виникає необхідність у вирішенні завдань, які постають на макро- та мікрорівнях перед економікою країни. За останні п’ятнадцять років економіки світу вже зазнавали спаду (наприклад, криза 2008 року), а в Україні економічна ситуація погіршується ще й у зв'язку з локальним військовим конфліктом, який також призводив до падіння національної економіки (рис. 1).

Незважаючи на достатню кількість наукових праць, присвячених кризовим явищам у різноманітних галузях економіки та розробленню шляхів виходу економіки 3 рецесії $[1 ; 2 ; 3]$, сьогодення приносить все більше неочікуваних факторів, що впливають на розвиток економік країн світу.

Мета статті. Метою статті є аналіз впливу пандемії на функціонування суб'єктів господарської діяльності будівельної галузі, економіку країн світу та пошук шляхів виходу із кризової ситуації.

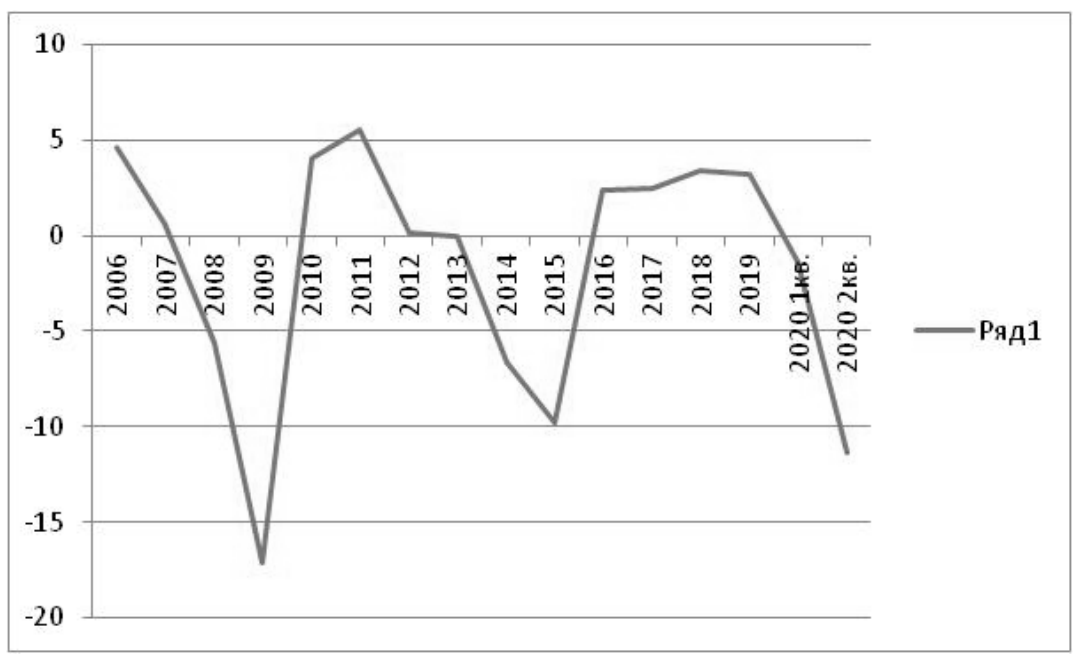

Рис. 1. Зміна реального ВВП в Україні

(у \% до відповідного кварталу попереднього року)

Джерело: побудовано за даними [5]

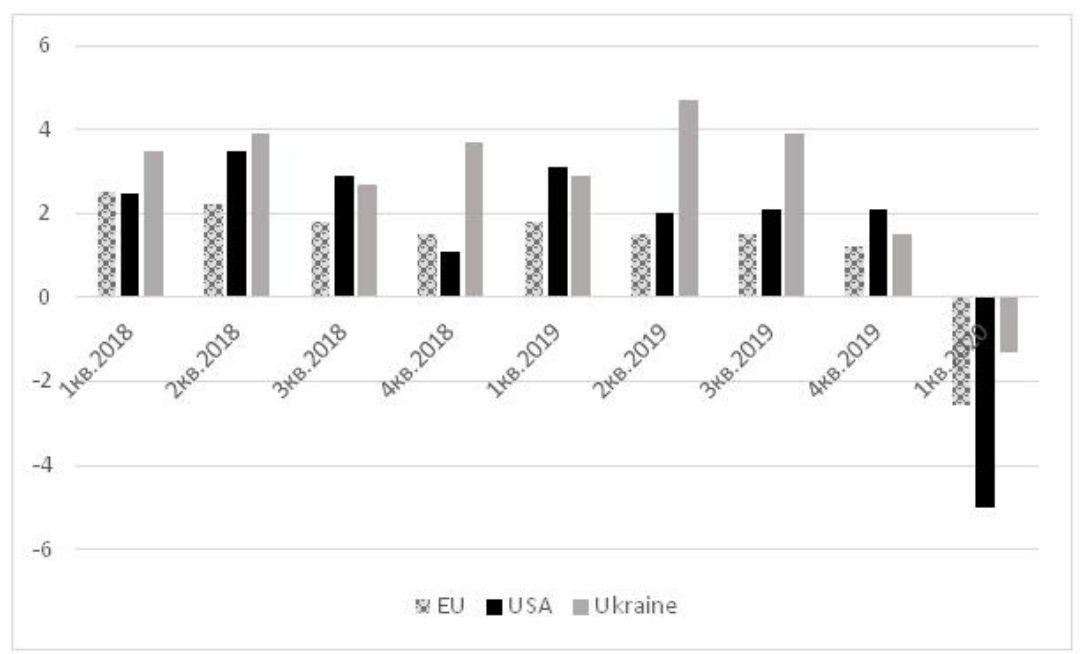

Рис. 2. Зміна реального ВВП (у \% до відповідного кварталу попереднього року) у країнах Свропейського Союзу, США та Україні Джерело: побудовано за даними [6; 7;8] 
Виклад основного матеріалу дослідження. У 2020 році на світ обрушилася пандемія вірусу SARSCoV-2, яка призвела до колапсу в економіці не тільки України, а і всього світу. Багато галузей економіки зазнали впливу форс-мажорних обставин, які зумовлені пандемією, і ввійшли в стан рецесії. Насамперед це зумовлено карантинними заходами, які були введені в багатьох країнах світу.

Відповідно до ст. 14 Закону України «Про торгово-промислові палати України», до форс-мажору (обставин непереборної сили) належали: загроза війни, стихійні лиха, пожежі, диверсії, блокада, вибухи, епідемія тощо [4]. Законом України «Про внесення змін до деяких законодавчих актів України, спрямованих на запобігання виникненню і поширенню коронавірусної хвороби (Covid-19)» від 17.03.2020 р. внесена поправка до вищезгаданого закону щодо віднесення до форс-мажорних обставин і введення карантину Кабінетом міністрів України [5].

Головною умовою функціонування будь-якого підприємства в нинішніх умовах пандемії є соціальне дистанціювання як у побутовій сфері життєдіяльності, так і в робочих реаліях. Як відзначає Всесвітня організація охорони здоров'я, вірус передається повітряно-крапельним шляхом, і мінімальна відстань між робітниками повинна бути не менше 1 метра. Крім цього, на самокарантин повинні бути відправлені особи, які контактували з людиною, зараженою вірусом (SARS-CoV-2) [11]. Будівництво якраз і $\epsilon$ тією сферою, яка може працювати без тісного контакту між працівниками, особливо зважаючи на те, що багато робіт у будівництві може виконуватися просто неба.

Виходячи $з$ даних сайтів Eurostat [6], BEA [7] та Державної служби статистики України [8], економіка багатьох країн не витримала впливу несподіваного зовнішнього фактору і впала до історичних мінімумів.

Але все ж така галузь економіки, як будівництво, в деяких країнах світу продемонструвала не лише зниження обсягів виконуваних робіт, а й навіть їх зростання.
Проаналізувавши внесок у ВВП України саме будівництва [8], можна побачити, що за останні 8 років галузь будівництва впевнено тримає одне з вагомих місць.

Якщо ж подивитися на кількість зайнятого населення у будівельній галузі в провідних економіках світу та Україні, то будівництво можна назвати не лише провідною галуззю в національній економіці, а й одним із лідерів у боротьбі із впливом форс-мажорних обставин на зайнятість населення.

Нині способами залучення робочого персоналу до виконання будівельних і монтажних робіт на об'єкті є:

1) використання постійного персоналу підприємства;

2) аутсорсинг (outsourcing) персоналу;

3) аутстафінг (outstaffing).

Під час залучення постійного персоналу підприємства найефективнішим методом організації будівельного процесу може стати потоковий метод, за якого досягаються оптимальні показники діяльності підприємства [9]. Він дає змогу:

- скоротити собівартість будівельних і монтажних робіт;

- досягти оптимальної продуктивності праці;

- зменшити тривалість виконання операцій.

Цей метод виконання робіт передбачає розбивку складного технологічного процесу на декілька простих операцій, що дає змогу виконувати такі операції одночасно на різних робочих місцях (різних об’єктах), що впливає на концентрацію виробничого персоналу на робочому місці й унеможливлює процес зараження великої кількості працівників.

Також для функціонування робітників на будівельних об'єктах можна запропонувати дроблення (crushing) бригад із метою взаємозаміни у разі виявлення носіїв вірусу в осередку персоналу.

Аутсорсинг та аутстафінг у будівельній галузі дає змогу повністю перекласти функцію забезпечення будівельного процесу виробничим персоналом на фірму-аутсорсера або фірму-провайдера (аутстафера) та досягти швидкої заміни спеціалізованої бригади у разі

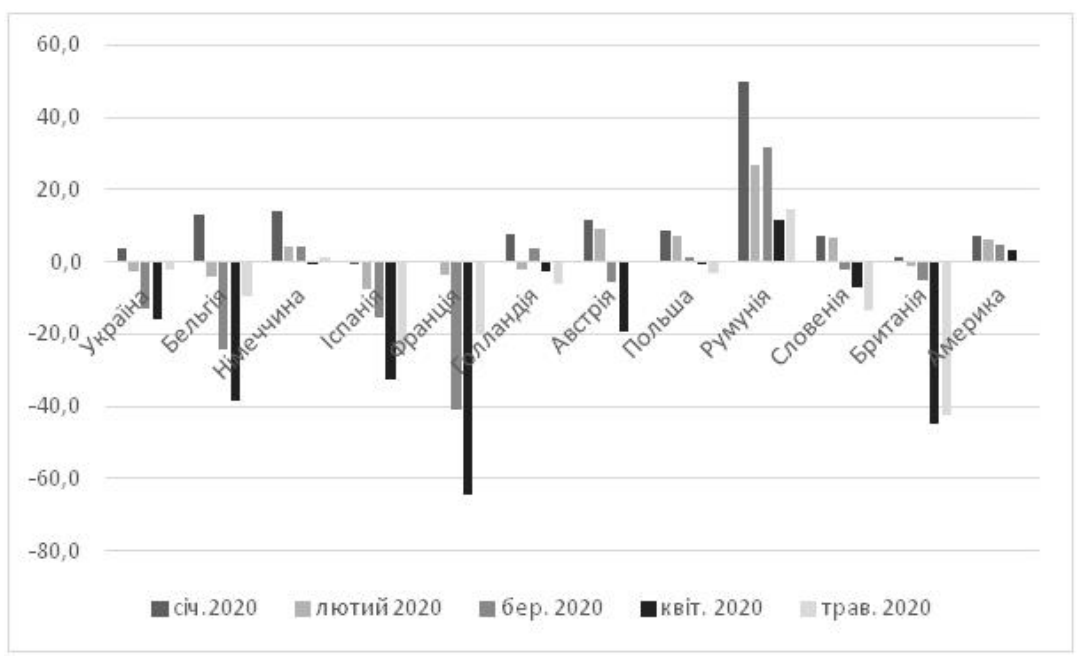

Рис. 3. Індекси будівельної продукції деяких свропейських країн, США та України (у \% до відповідного періоду попереднього року)

Джерело: побудовано за даними [6; 7; 8] 
Таблиця 1

ВВП України виробничим методом за видами економічної діяльності (у \% до підсумку)

\begin{tabular}{|c|c|c|c|c|c|c|c|c|}
\hline Код КВЕД & $\mathbf{2 0 1 2}$ & $\mathbf{2 0 1 3}$ & $\mathbf{2 0 1 4}$ & $\mathbf{2 0 1 5}$ & $\mathbf{2 0 1 6}$ & $\mathbf{2 0 1 7}$ & $\mathbf{2 0 1 8}$ & $\mathbf{2 0 1 9}$ \\
\hline $\mathbf{A}$ & 7,8 & 8,8 & 10,2 & 12,1 & 11,7 & 10,2 & 10,1 & 9,0 \\
\hline $\mathbf{B}$ & 5,8 & 5,5 & 5,0 & 4,8 & 5,5 & 5,9 & 6,0 & 5,6 \\
\hline $\mathbf{C}$ & 12,4 & 11,3 & 12,2 & 11,9 & 12,2 & 12,1 & 11,6 & 10,8 \\
\hline $\mathbf{D}$ & 3,1 & 2,9 & 2,8 & 2,7 & 3,1 & 2,9 & 3,1 & 3,1 \\
\hline $\mathbf{F}$ & 2,8 & 2,5 & 2,3 & 2,0 & 2,0 & 2,2 & 2,3 & 2,7 \\
\hline $\mathbf{G}$ & 14,3 & 14,5 & 14,7 & 13,8 & 13,3 & 13,7 & 13,3 & 13,2 \\
\hline $\mathbf{H}$ & 7,0 & 7,1 & 6,4 & 6,8 & 6,6 & 6,4 & 6,4 & 6,8 \\
\hline $\mathbf{J}$ & 3,1 & 3,3 & 3,3 & 3,7 & 3,7 & 3,7 & 3,9 & 4,5 \\
\hline $\mathbf{K}$ & 4,3 & 4,5 & 4,4 & 3,4 & 2,7 & 2,7 & 2,7 & 2,8 \\
\hline $\mathbf{L}$ & 5,9 & 6,5 & 6,2 & 6,2 & 6,1 & 5,8 & 5,8 & 6,2 \\
\hline $\mathbf{M}$ & 3,0 & 3,3 & 3,0 & 2,8 & 2,9 & 2,9 & 3,2 & 3,5 \\
\hline $\mathbf{O}$ & 4,3 & 4,7 & 5,0 & 4,8 & 5,2 & 5,5 & 6,0 & 6,7 \\
\hline $\mathbf{P}$ & 5,1 & 5,3 & 4,8 & 4,2 & 3,7 & 4,5 & 4,5 & 4,4 \\
\hline
\end{tabular}

А - сільське господарство, лісове господарство та рибне господарство, В - добувна промисловість і розроблення кар'єрів, $\mathrm{C}$ - переробна промисловість, D - постачання електроенергії, газу, пари та кондиційованого повітря, F - будівництво, $\mathrm{G}$ - оптова та роздрібна торгівля, $\mathrm{H}$ - транспорт, складське господарство, поштова та кур'єрська діяльність, J - інформація та телекомунікації, $\mathrm{K}$ - фінансова та страхова діяльність, L - операції з нерухомим майном, $\mathrm{M}$ - професійна, наукова та технічна діяльність, О - державне управління й оборона; обов'язкове соціальне страхування, Р - освіта.

Джерело: [8]

необхідності. Залучення стороннього персоналу до здійснення виробничого процесу дасть змогу не допускати простоїв у виконанні будівельних, монтажних та спеціалізованих робіт на об'єктах будівництва.

За договорами аутсорсингу та аутстафінгу, виробничий персонал не входить у постійний персонал будівельної організації, а додаткові витрати, пов'язані з утриманням персоналу, не відображаються на роботі підприємств будівельної галузі і дають змогу оптимізувати виробничий процес.

Таким чином, такі сучасні методи залучення персоналу в будівництві, як аутсорсинг та аутстафінг, дають можливість швидкого виявлення носія вірусу та ізоляції окремої бригади з метою нерозповсюдження зараження серед робітників підприємства на об'єктах, що будуються.
Висновки. Сучасні суб'єкти господарської діяльності опинилися майже беззахисними перед впливом форсмажорних обставин, які викликані розповсюдженням пандемії у світі (SARS-CoV-2). Для нейтралізації дії негативних факторів підприємства повинні бути підготовленими до продовження своєї діяльності у будь-яких важких умовах функціонування. Кожне підприємство повинно швидко реагувати на неймовірні виклики сьогодення і забезпечувати безпечну і безперебійну роботу в умовах глобальних катаклізмів. Зважаючи на те, що будівництво - одна 3 галузей економіки, яка не може функціонувати онлайн, кожному підприємству необхідно мати підготовлений комплекс заходів для протистояння форс-мажорним обставинам, для максимального збереження потенціалу виробничого персоналу.

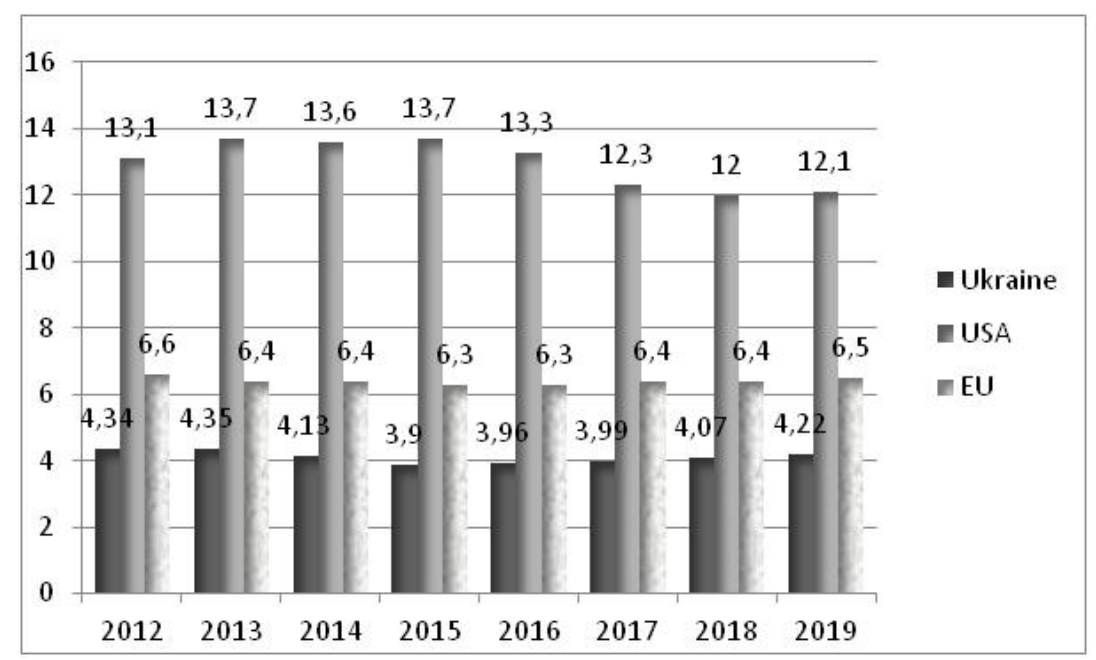

Рис. 4. Частка зайнятого населення у будівництві в Україні, США та Свропейському Союзі

(у \% до загальної кількості працездатного населення)

Джерело: побудовано за даними [6; 8; 10] 
Список літератури.

1. Кондратчук К.С. Сутність і причини кризових проявів у світовій економічній системі. Актуальні проблеми економіки. № 1(103). 2010.

2. Мамчин М.М. Особливості і наслідки впливу світової фінансово-економічної кризи на економіку України / М.М. Мамчин, Ю.В. Шамро // Збірник наукових праць Національного університету державної податкової служби України. 2011. № 2. С. 171-179.

3. Созанський Й. Економічне стимулювання діяльності будівельних підприємств. Економіка. Фінанси. Право. 2016. № 1(1). С. 52-55.

4. Закон України «Про Торгово-промислові палати в Україні». URL: https://zakon.rada.gov.ua/laws/show/671/97\%D0\%B2\%D1\%80\#Text (дата звернення: 31.08.2020).

5. Закон України «Про внесення змін до деяких законодавчих актів України, спрямованих на запобігання виникненню і поширенню корона вірусної хвороби (COVID-19)». URL: https://zakon.rada.gov.ua/laws/show/ 530-20\#n38 (дата звернення: 31.08.2020).

6. Статистична інформація. Статистичне управління Европейського Союзу. URL: https:/ec.europa.eu/eurostat/ web/national-accounts (дата звернення: 29.08.2020).

7. Статистична інформація. Бюро економічного аналізу Департаменту комерції США. URL: https://www.bea.gov/ (дата звернення: 29.08.2020).

8. Статистична інформація. Державна служба статистики України. URL: http://www.ukrstat.gov.ua/ (дата звернення: 28.08.2020).

9. Організація будівництва / С.А. Ушацький та ін.; За ред. С.А. Ушацького. Підручник. Київ : Кондор, 2007.521 с.

10. Статична інформація. Урядове агентство Сінгапура. URL: https://stats.mom.gov.sg/Pages/EmploymentSummary-Table.aspx (дата звернення 29.08.2020)

11. Рекомендіції ВО3 для населення. Всесвітня організація охорони здоров'я. URL: https://www.who.int/ru/ emergencies/diseases/novel-coronavirus-2019/advice-for-public/q-a-coronaviruses (дата звернення: 25.08.2020).

\section{Referenses:}

1. Kondratchuk K.S. (2010) Sutnistj i prychyny kryzovykh projaviv u svitovij ekonomichnij systemi [The essence and causes of crisis manifestations in the world economic system]. Aktualjni problemy ekonomiky, no. 1(103).

2. Mamchyn M.M., Shamro Yu.V. (2011) Osoblyvosti i naslidky vplyvu svitovoji finansovo-ekonomichnoji kryzy na ekonomiku Ukrajiny [Features and consequences of the global financial and economic crisis on the economy of Ukraine]. Zbirnyk naukovykh pracj Nacionaljnogho universytetu derzhavnoji podatkovoji sluzhby Ukrajiny, no. 2, pp. $171-179$.

3. Sozansjkyj J. (2016) Ekonomichne stymuljuvannja dijaljnosti budiveljnykh pidpryjemstv [Economic stimulation of construction enterprises]. Ekonomika. Finansy. Pravo, no. 1(1), pp. 52-55.

4. Zakon Ukrajiny «Pro Torghovo-promyslovi palaty v Ukrajini» [Law of Ukraine on Torghovo-promyslovi palaty in Ukraine]. Available at: https://zakon.rada.gov.ua/laws/show/671/97-\%D0\%B2\%D1\%80\#Text (accessed 31.08.2020).

5. Zakon Ukrajiny «Pro vnesennja zmin do dejakykh zakonodavchykh aktiv Ukrajiny, sprjamovanykh na zapobighannja vynyknennju i poshyrennju koronavirusnoji khvoroby (COVID-19)» [The Law of Ukraine «On amendments to some legislative acts of Ukraine aimed at preventing the emergence and spread of viral diseases crown (COVID-19)»]. Available at: https://zakon.rada.gov.ua/laws/show/530-20\#n38 (accessed 31.08.2020).

6. Statystychna informatsiia [Statistical Information]. Staty`sty`chne upravlinnya Evropejs`kogo Soyuzu. Available at: https://ec.europa.eu/ eurostat/web/national-accounts (accessed 29.08.2020).

7. Statystychna informatsiia [Statistical Information]. Bjuro ekonomichnogho analizu Departamentu komerciji SShA. Available at: https://www. bea.gov/ (accessed 29.08.2020).

8. Statystychna informatsiia [Statistical Information]. Derzhavna sluzhba statystyky Ukrajiny. Available at: http://www.ukrstat.gov.ua/ (accessed 28.08.2020).

9. Ushacjkyj C.A. ta in. (2007) Orghanizacija budivnyctva [Organization of construction] / In I.P. C.A. Ushacjkogho. Pidruchnyk. Kiyiv: Kondor.

10. Statystychna informatsiia [Statistical Information]. Uryadove agentstvo Singapura. Available at: https://stats.mom.gov.sg/Pages/Employment-Summary-Table.aspx (accessed 29.08.2020).

11. Rekomendiciyi VOZ dlya naselennya [WHO recommendations for the population]. World Health Organization. Available at: https://www.who.int/ru/emergencies/diseases/novel-coronavirus-2019/advice-for-public/q-a-coronaviruses (accessed 25.08.2020). 